\title{
COOPERAÇÃO INTERNACIONAL PARA A PRESERVAÇÃO DO MEIO AMBIENTE: O DIREITO BRASILEIRO E A CONVENÇÃO DE AARHUS
}

\author{
Valerio de Oliveira Mazzuoli e Patryck de Araújo Ayala
}

\section{RESUMO}

O ARTIGO EXAMINA A COOPERAÇÃO INTERNACIONAL PARA A PRESERVAC̣Ão dO MEIO AMBIENTE NA LEI DOS CRIMES AMBIENTAIS E PROPÕE O SEU ENTENDIMENTO À LUZ DAS REGRAS DO DIREITO INTERNACIONAL PÚBLICO, ESPECIALMENTE SOB A ÓPTICA DA Convenç̃̃o de AARHUS de 1998 SOBRE ACESSO À INFORMACÃa, PARTICIPAC̣ÃO DO PÚBLICO NO PROCESSO DE TOMADA DE DECISÃO E ACESSO À JUSTICCA EM MATÉRIA AMBIENTAL. TRATA-SE DE UMA PESQUISA BIBLIOGRÁFICA, SENDO UTILIZADAS LEGISLAC̣ÃO E DOUTRINA, TANTO PRODUZIDA NO BRASIL QUANTO NO DIREITO COMPARADO. OS RESULTADOS ALCANÇADOS DEMONSTRAM QUE O ACESSO À INFORMACCÃO DE CUNHO AMBIENTAL É FUNDAMENTAL AO APERFEIÇOAMENTO DE UMA CULTURA GLOBAL DE COOPERAÇĀO, SENDO FUNDAMENTAL A INFORMACÃO, PARTICIPACÃO E INTERFERÊNCIA DA COLETIVIDADE NOS PROCESSOS DE DECISÃO AMBIENTALMENTE RELEVANTES. O ENSAIO CONCLUI QUE A CONVENÇ̄̃o DE AARHUS, CONQUANTO AINDA NÃO RATIFICADA PELO BRASIL, SERVE DE PARADIGMA À LEGISLACĀO DOMÉSTICA COM RELAÇÃO AO DEVER DE COOPERAR INTERNACIONALMENTE PARA FINS DE PRESERVAÇ̃̃O DO MEIO AMBIENTE.

\section{PALAVRAS-CHAVE}

COOPERAÇÃo INTERnACIONAL Ambiental; LeI dOS CRIMES Ambientais; Convenç̧ão de Aarhus; PrincípIo da precaução: ACESSO A INFORMACÃO.
INTERNATIONAL COOPERATION FOR THE PRESERVATION OF THE ENVIRONMENT: THE BRAZILIAN LAW AND THE AARHUS CONVENTION

\section{ABSTRACT}

THIS ARTICLE EXAMINES THE INTERNATIONAL COOPERATION FOR ENVIRONMENTAL PRESERVATION IN THE ENVIRONMENTAL CRIMES LAW, AND SUGGESTS THAT THE LAW CAN BE UNDERSTOOD IN LIGHT OF THE RULES OF INTERNATIONAL PUBLIC LAW, ESPECIALLY FROM THE VIEWPOINT OF THE AARHUS CONVENTION OF 1998 REGARDING ACCESS TO INFORMATION, PUBLIC PARTICIPATION IN THE DECISIONMAKING AND ACCESS TO JUSTICE IN ENVIRONMENTAL MATTERS. THE RESULTS SHOW THAT ACCESS TO INFORMATION OF ENVIRONMENTAL NATURE IS ESSENTIAL TO THE DEVELOPMENT OF A GLOBAL CULTURE OF COOPERATION IS FUNDAMENTAL TO INFORMATION, PARTICIPATION AND INTERFERENCE OF THE COMMUNITY IN DECISION-MAKING ENVIRONMENTALLY RELEVANT. THE ESSAY CONCLUDES THAT THE AARHUS CONVENTION, WHILE STILL NOT RATIFIED BY BRAZIL, SHOULD SERVE AS A PARADIGM FOR DOMESTIC LEGISLATION IN TERMS OF THE OBLIGATION FOR INTERNATIONAL COOPERATION IN ORDER TO PROTECT THE ENVIRONMENT.

\section{KEYWORDS}

INTERNATIONAL ENVIRONMENTAL COOPERATION:

EnVironmental Crimes LaW; Aarhus Convention; PRECAUTIONARY PRINCIPLE; ACCESS TO INFORMATION.

\section{INTRODUÇÃO}

Este ensaio tem por finalidade estudar o instituto da cooperação internacional para a preservação do meio ambiente, tal como delineado nos artigos 77 e 78 da Lei 9.605, de 12 de fevereiro de 1998, ${ }^{1}$ conjugadamente à Convenção de Aarhus de 1998 sobre 
acesso à informação, participação do público no processo de tomada de decisão e acesso à justiça em matéria ambiental.

Naqueles artigos da Lei 9.605/1998 - conhecida como Lei dos Crimes Ambientais há dois deveres claramente provindos do Direito Internacional do Meio Ambiente, respectivamente, o dever de cooperar (art. 77) e a obrigação de informar (art. 78). ${ }^{2}$ Assim, o que se pretende demonstrar nas linhas seguintes é que os deveres a que o Estado brasileiro se impôs por meio da Lei dos Crimes Ambientais devem ser interpretados à luz das regras do contemporâneo Direito Internacional Público, especialmente na sua vertente ambiental conhecida como Direito Internacional do Meio Ambiente (Mazzuoli, 2011, p. 977-984).

Para se chegar a esse desiderato, primeiramente será investigado (a) o fundamento da cooperação internacional em matéria ambiental, analisando-se depois (b) o Estado ambiental e o dever de reduzir os riscos à qualidade dos recursos naturais. Posteriormente, será estudada (c) a proteção penal do meio ambiente no contexto de uma cultura global de acesso à informação, com ênfase naquilo que se chamou de "tripé de Aarhus". Na sequência, será explicado (d) o princípio da precaução no quadro de uma cultura global de acesso à informação e a influência exercida pelo "tripé de Aarhus" nesse contexto. Entende-se que somente estudando essas vertentes de Aarhus (em que também se contextualiza a cooperação stricto sensu) é que se poderá compreender o tema objeto deste estudo. Por fim, será analisado (e) o dever de cooperação entre Estados na proteção penal do meio ambiente, seguindo-se (f) as conclusões.

\section{Fundamento dA COOPERAÇÃo INTERnACIONAL EM MATÉRIA AMBIENTAL}

Os problemas decorrentes da degradação ambiental têm assumido alcance cada vez mais global, tornando premente a soma de esforços dos Estados a fim de evitá-los, impedindo também novos danos ao meio ambiente como meio de resguardar as gerações futuras. Essa ação conjunta estatal se faz por meio do instituto da cooperação internacional, que encontra na seara ambiental um universo vasto de possibilidades e também desafios.

Sem dúvida alguma, uma das formas de cooperação entre Estados mais importantes atualmente existentes diz respeito ao tema do meio ambiente. No Brasil foi a chamada Lei dos Crimes Ambientais (Lei 9.605/1998) que disciplinou, no seu Capítulo VII, a cooperação internacional para a preservação do meio ambiente (arts. 77 e 78).

Ainda que prevista numa lei sobre crimes ambientais, a cooperação internacional em apreço é obrigação instrumental que provém diretamente do Direito Internacional desde o final da $2^{\text {a }}$ Guerra (Soares, 2003, p. 480-488). Por esse motivo o tema da cooperação internacional para a preservação do meio ambiente - ainda que disciplinado, no Brasil, por uma lei de cunho criminal -, ultrapassa o âmbito legislativo no qual eventualmente se insere em uma dada ordem jurídica. ${ }^{3}$ 
Cabe destacar que o termo "cooperação" começou a ganhar ênfase no plano internacional com a Carta das Nações Unidas $\left(\operatorname{art} .1^{\circ}, \S 3^{\circ}\right.$ ), quando ali se previu ser um dos propósitos da ONU “conseguir uma cooperação internacional para resolver os problemas internacionais de caráter econômico, social, cultural ou humanitário, e para promover e estimular o respeito aos direitos humanos e às liberdades fundamentais para todos, sem distinção de raça, sexo, língua ou religião" (Mazzuoli, 2011, p. 620-621). Mais enfaticamente a mesma Carta disciplinou a cooperação "econômica e social" nos artigos 55 e 56, assim redigidos:

Artigo 55

Com o fim de criar condições de estabilidade e bem-estar, necessárias às relações pacíficas e amistosas entre as Nações, baseadas no respeito ao princípio da igualdade de direitos e da autodeterminação dos povos, as Nações Unidas favorecerão:

a) níveis mais altos de vida, trabalho efetivo e condições de progresso e desenvolvimento econômico e social;

b) a solução dos problemas internacionais econômicos, sociais, sanitários e conexos; a cooperação internacional, de caráter cultural e educacional; e

c) o respeito universal e efetivo dos direitos humanos e das liberdades fundamentais para todos, sem distinção de raça, sexo, língua ou religião.

\section{Artigo 56}

Para a realização dos propósitos enumerados no artigo 55, todos os membros da Organização se comprometem a agir em cooperação com esta, em conjunto ou separadamente.

Especificamente no que tange à cooperação para fins de proteção e melhoramento do meio ambiente, o Princípio 24 da Declaração de Estocolmo sobre o Meio Ambiente Humano (1972) dispôs o seguinte:

Todos os países, grandes ou pequenos, devem empenhar-se com espírito de cooperação e em pé de igualdade na solução das questões internacionais relativas à proteção e melhoria do meio. É indispensável cooperar mediante acordos multilaterais e bilaterais e por outros meios apropriados, a fim de evitar, eliminar ou reduzir, e controlar eficazmente os efeitos prejudiciais que as atividades que se realizem em qualquer esfera possam acarretar para o meio, levando na devida conta a soberania e os interesses de todos os Estados.

No Fórum de Siena (17-21.04.1990), preparatório para a Conferência do Rio de Janeiro de 1992, o dever de cooperação entre Estados para a preservação do meio ambiente ficou assim colocado: 
A obrigação de cooperar manifesta-se como um dever de agir de boa-fé, a fim de atingir-se uma meta de interesse geral, em face dos Estados diretamente envolvidos, representando também o interesse da comunidade internacional no seu conjunto. Traçar uma lista de ações precisas a serem levadas a cabo é uma tarefa impossível, pois cada situação deve ser avaliada à luz das características específicas em cada caso. Contudo, podem-se citar algumas ações-tipo de cooperação, referentes aos Estados. Trata-se, em particular, das obrigações relativas à informação, à notificação, à assistência mútua e à negociação. Tais ações, frequentemente, completam os sistemas de proteção do meio ambiente elaborados pelo Direito Internacional.

Na Declaração do Rio de Janeiro sobre Meio Ambiente e Desenvolvimento (1992) o tema voltou à tona, tendo o seu Princípio 7 estabelecido que "os Estados irão cooperar, em espírito de parceria global, para a conservação, proteção e restauração da saúde e da integridade do ecossistema terrestre".

No âmbito do Mercosul cabe destacar o Acordo Quadro sobre Meio Ambiente do Mercosul, celebrado em Assunção (Paraguai), em 22 de junho de 2001, e ratificado pelo Brasil em 9 de outubro de 2003, ${ }^{4}$ que ressalta, logo em seu segundo considerando, a necessidade "de cooperar para a proteção do meio ambiente e para a utilização sustentável dos recursos naturais, com vistas a alcançar a melhoria da qualidade de vida e o desenvolvimento econômico, social e ambiental sustentável”.

Serão todas essas normas internacionais paradigmas para a cooperação internacional em matéria de proteção do meio ambiente, tal como previsto por diversas legislações contemporâneas e, no Brasil, pela Lei 9.605/1998, nos seus artigos 77 e 78 . Tais dispositivos refletem, portanto, o engajamento do Estado brasileiro para com a proteção do meio ambiente, nas ordens nacional e internacional, ${ }^{5}$ especialmente (mas não exclusivamente) na seara da cooperação para fins penais, de acordo com as regras nacionais sobre o tema e com os tratados internacionais dos quais a República Federativa do Brasil é parte.

Todavia, ainda que não existissem os artigos 77 e 78 da Lei dos Crimes Ambientais em nossa ordem jurídica, a obrigação do Estado brasileiro de cooperar (não somente em matéria penal) com outros países se faria presente, uma vez que o Brasil é parte dos principais tratados em matéria de proteção do meio ambiente, que têm inclusive status diferenciado na ordem jurídica interna (no nosso entender esse status é de "norma constitucional”), ${ }^{6}$ por pertencerem à categoria dos tratados de direitos humanos lato sensu. Outro motivo é ter a Constituição Federal de 1988 consagrado, no seu artigo $4^{\circ}$, II e IX, os princípios da prevalência dos direitos humanos e da cooperação entre os povos para o progresso da humanidade, em que indubitavelmente se inclui a proteção do meio ambiente, nestes termos: "Art. $4^{\circ} \mathrm{A}$ República Federativa do Brasil rege-se nas suas relações internacionais pelos seguintes princípios: (...) 
II - prevalência dos direitos humanos; (...) IX - cooperação entre os povos para o progresso da humanidade".

O professor Guido Soares (2003, p. 493-494) bem esclarece o que se entende por cooperação lato sensu, esta abrange

... as ações conjuntas levadas a cabo entre todos os Estados ou por certo número de Estados, com vista em determinado fim, seja aquelas concertadas em níveis bilateral ou multilateral (dentro dos mecanismos existentes no interior de organizações ou entidades institucionalizadas ou em operações ad hoc), seja aquelas decorrentes de um dever instituído por uma norma não escrita.

O autor complementa que em razão da finalidade a que se propõe

... pode assumir várias formas, tais como: a cooperação político-militar (formação de alianças, blocos militares, com finalidades de defesa externa comum entre os parceiros, formação de forças de intervenção sob a égide da ONU), de integração econômica regional (em vários graus de supranacionalidade, como as áreas de livre comércio, as uniões aduaneiras, as zonas de mercado comum e as uniões econômicas, a integração física (com diversos tipos de empresas de gestão de recursos havidos em comum entre dois ou mais Estados), a cooperação técnica internacional (nas formas de assistência técnica internacional, transferência internacional de tecnologia e transferência internacional de capitais, devendo-se assinalar que os recursos humanos e/ou financeiros envolvidos na cooperação técnica internacional podem provir de fundos públicos - a cooperação interestatal propriamente dita - ou de quaisquer outros, a depender das formas que possam assumir as transferências de recursos: contratos entre Estados ou empresas sob seu controle e bancos ou entidades privadas estrangeiras, a título concessional ou não, doações de entidades de benemerência, contratos entre particulares submetidos a jurisdições de Estados distintos etc.). ${ }^{7}$

Levando-se em conta que cooperar significa "operar simultaneamente, colaborar, trabalhar em comum, ajudar ou participar” (Rossit, 2006, p. 164), tem-se que a finalidade primeira da cooperação internacional em matéria ambiental é prevenir os atos (dos Estados ou de particulares) que de qualquer maneira possam degradar o meio ambiente, uma vez que este (meio ambiente) não conhece qualquer tipo de fronteira ou limitação geográfica (Milaré, 2009, p. 1229). Daí a necessidade de normativas ambientais (internacionais e nacionais) que prevejam a atuação conjunta das nações como necessária à efetiva proteção do meio ambiente. Tudo isso, seguramente, é 
reflexo da "dimensão transfronteiriça e global das atividades degradadoras exercidas no âmbito das jurisdições nacionais” (Mirra, 1996, p. 65).

Como se falou, o Estado brasileiro se obriga, por meio de lei, a cooperar internacionalmente para a preservação do meio ambiente. Neste estudo entendeu-se importante dar destaque menos para o primeiro dever (o de cooperar) previsto na Lei dos Crimes Ambientais (art. 77), do que para a segunda obrigação proveniente da mesma Lei, relativa à informação, tal como prevista no artigo 78 (obrigação para a qual existe norma internacional disciplinadora - a Convenção de Aarhus de 1998 -, tal como se analisará adiante). Portanto, a análise que se fará a seguir está voltada prioritariamente para esse dever de informar.

\section{ESTADO AMBIENTAL E O DEVER DE REDUZIR OS RISCOS À QUALIDADE DOS RECURSOS NATURAIS}

É premente compreender o que se entende por "Estado ambiental" e o que significa o dever de reduzir os riscos à qualidade dos recursos naturais, antes de se adentrar na análise do dever de informar de que trata o artigo 78 da Lei dos Crimes Ambientais, no plano do Direito brasileiro, e a Convenção de Aarhus de 1998, na órbita do Direito Internacional Público.

Inicialmente, cabe destacar que a influência de uma ordem pública global sobre o sentido das ações políticas no Direito brasileiro pode ser visualizada já a partir de sua arquitetura constitucional, que encontra seu fundamento em um dever geral de solidariedade para com a humanidade, mensagem emancipatória que foi considerada no âmbito de um projeto político de sociedade que prioriza e enfatiza o bem-estar coletivo como tarefa determinante da qual depende a manutenção da ordem pública e social.

Sob esse contexto, ganha ênfase a posição angular que recebe o "princípio da dignidade da pessoa humana"8 em semelhante regime de governança, que projeta suas consequências em realidades sociais e ecológicas da existência da pessoa nesse espaço público.

Baseado nesse primado da dignidade (art. $1^{\circ}$, III, da CF/1988) e em um dever geral de solidariedade para com a humanidade (arts. $3^{\circ}$, I, e 225, caput, da CF/1988), modificações substanciais podem ser constatadas no projeto de ordem social proposto pela atual Constituição brasileira, o qual também se projeta como uma tendência em visível expansão em outras experiências ocidentais. ${ }^{9}$

A afirmação política e normativa de um objetivo de solidariedade e de compromisso para com as gerações presentes e futuras, como os que se encontram expressos nos artigos $3^{\circ}$, III, e 225, caput, da CF/1988, impõem a sujeição do Estado e dos particulares ao dever de autorrestrição no livre exercício da autonomia da vontade.

Nem todas as escolhas são toleráveis e admissíveis pelo projeto de sociedade (que, neste caso, também é um projeto de futuro) definido pela ordem constitucional 
brasileira. Cumpre às funções estatais obstar excessos na definição das escolhas sobre como é possível e como se desenvolverá a existência da humanidade. Isso porque o excesso no exercício de tal capacidade de escolha e a sujeição dessa sociedade a determinados modelos de desenvolvimento, incapazes de assegurar a existência de todas as formas de vida, representam comportamentos de deslealdade com semelhante proposta de cultura constitucional que orienta o modelo contemporâneo de um Estado comprometido com tarefas sociais, econômicas, culturais e ecológicas.

Em um modelo de Estado exposto a exigentes desafios e tarefas capazes de interferir em realidades existenciais de longo curso, a dignidade da pessoa humana passa a constituir-se em postulado primário para a compreensão do alcance que tais objetivos de proteção (antes associados a uma dimensão antropocêntrica de uma existência efêmera) passaram a assumir nas sociedades presentes no mundo contemporâneo.

A dignidade humana, situada como primado que condiciona a realização das tarefas estatais, adquire um significado diferenciado quando contextualizada perante um conjunto de valores de uma sociedade plural e de uma comunidade moral axiologicamente complexa, contribuindo, v.g., para a afirmação da inclusão dos animais não humanos e da natureza na esfera protetiva, conjuntura que só se faz possível porque a definição dos valores que devem ser protegidos vincula-se e está fundamentada em uma ordem permanentemente aberta. Esta, por sua vez, tem na configuração contemporânea de Estado sua manifestação jurídico-política. ${ }^{10}$

Considerando-se o conjunto dos argumentos analisados, e se é correto admitir que a sobrevivência e o livre desenvolvimento da personalidade das pessoas dependem de que sejam garantidos ou mantidos determinados níveis de qualidade aos recursos naturais em geral, é possível atribuir à natureza a condição de bem, que manifesta um valor independente de suas utilidades econômicas ou da satisfação de necessidades humanas imediatas, razão pela qual as ordens constitucionais atuais, situadas que estão no contexto de projetos emancipatórios de qualidade diferenciada, tendem a reconhecer e a exprimir o valor de existência da natureza (e o valor de existência de outras formas de vida) como manifestação de um pluralismo moral na definição das tarefas estatais de proteção.

A tarefa estatal de assegurar o bem-estar ganha, portanto, a partir da afirmação de um Estado ambiental, dimensões bem mais extensas em relação ao alcance de semelhante dever. Este lhe impõe severas exigências de escala para a consecução da tarefa de assegurar o bem-estar social, pois os valores da sociedade que se quer proteger estão vinculados agora aos interesses de titulares e beneficiários que ainda não participam da comunidade política, a saber, os animais não humanos e, principalmente, as gerações vindouras. ${ }^{11}$

Isso somente se faz possível a partir de um modelo de cultura constitucional fundado em um pluralismo moral (responsável pelo alargamento da comunidade moral que justifica os interesses protegidos), pressuposto indispensável para que o sentido do 
primado da dignidade da pessoa humana possa proporcionar uma proteção reforçada para todos aqueles que têm algum interesse afetado e possam, de algum modo, compreender e vivenciar o valor dignidade.

Decorre do direito (humano e fundamental) ao meio ambiente um conjunto de deveres estatais e sociais de garantia da qualidade de vida, sob uma perspectiva pela qual esta é o efeito da combinação de um complexo de variáveis (econômicas, sociais, culturais, ambientais, etc.). Tem-se, aqui, um direito econômico, social e cultural, também garantido pelo Direito Internacional por meio de convenções específicas, cujo exemplo mais concreto é o Pacto Internacional dos Direitos Econômicos, Sociais e Culturais (celebrado em Nova York, em 1966, sob os auspícios das Nações Unidas). ${ }^{12}$ De sua realidade objetiva pode-se reconhecer um conjunto de deveres, todos vinculados a uma meta de aperfeiçoamento da proteção, que somente pode ser atingida mediante a redução dos níveis de risco a que a coletividade se encontra exposta diariamente (Sands, 2004, p. 22-28).

Não se trata de um dever exclusivamente estatal, senão de um dever social. Todos devem ser capazes de mitigar os efeitos externos de suas escolhas, e há de ser o exercício das liberdades econômicas condicionado pela necessidade de assegurar que o desenvolvimento da vida se estenda de forma duradoura.

O dever (estatal e social) de reduzir os riscos envolve escolhas em longo prazo e compromissos permanentes para com o desenvolvimento da vida e de todas as formas de vida, sendo este o objetivo de maior proeminência de um Estado ambiental.

Elevar os níveis de qualidade de vida requer um forte compromisso com a redução dos riscos existenciais. Nesse sentido, um Estado que adote legislação interna conforme as normas internacionais de proteção (tanto na seara dos direitos humanos lato sensu, como do direito ambiental stricto sensu) é um Estado mais apto a reduzir os riscos existenciais, elevando consequentemente os níveis de qualidade de vida.

Esses dois objetivos do Estado ambiental - reduzir os riscos existenciais e elevar os níveis de qualidade de vida - não fazem com que o Estado deixe de ser um Estado social, mas comungam esforços para que seja um Estado no qual o objeto da proteção social é alargado para alcançar elementos ecológicos, como parte integrante desse projeto existencial de qualidade de vida.

É nesse contexto, social, político e, agora, jurídico, que o tema da cooperação internacional para a proteção do meio ambiente há de ser examinado.

Tem-se, aqui, um paradoxo vinculado ao contexto de riscos contemporâneos, que se encontra posicionado como veículo de conflitos, ao menos na experiência jurídica brasileira, os quais serão considerados a partir de uma imagem político-jurídica de um Estado ambiental.

Em um Estado ambiental exposto a ameaças e aos efeitos de problemas ambientais de segunda geração, ${ }^{13}$ somente se pode conceber uma proteção reforçada para os interesses de uma comunidade moral heterogênea e complexa a partir de um reforço sobre 
a própria consideração do primado da dignidade da pessoa humana, situado que está agora em uma cultura constitucional moralmente plural.

Só se pode conceber dignidade a partir de uma referência deôntica que considera a coletividade sob uma perspectiva de escala diferenciada, vinculada à noção de humanidade. Portanto, o dever estatal e os deveres fundamentais atribuídos a cada membro dessa comunidade política não se esgotam (no projeto de sociedade delineado pela Constituição brasileira) na garantia do bem-estar e na qualidade de vida desses mesmos membros, senão apontam para uma tarefa (estatal) e para deveres (estatais e sociais) perante toda a humanidade. O princípio da dignidade da pessoa humana impõe, nessa direção, deveres estatais e deveres fundamentais sujeitos a uma escala exigente de concretização.

A própria definição do conteúdo das tarefas públicas é visivelmente influenciada pela modificação das relações de poder que se desenvolvem em escala global, bem como pelos objetivos e pelos consensos obtidos em um espaço multilateral de negociações. Perante a constatação de ameaças que podem comprometer a existência da humanidade, faz-se necessário que os Estados se responsabilizem com semelhante tarefa também no plano nacional, e por meio do exercício das funções legislativa, executiva e judiciária, para que possa ser atingido o objetivo de redução dos riscos. Esse resultado decorre, assim, de deveres ou de decisões públicas cujo conteúdo tem seu fundamento último em um compromisso que não é exclusivamente nacional. A atuação legislativa, por meio de legislação e de procedimentos que asseguram a redução das emissões, e de suas fontes, ocorre no plano nacional, mas suas consequências se projetam em escalas espaciais diferenciadas, em maior ou menor grau.

Sendo assim, resulta visível que as consequências das escolhas públicas têm origem cada vez menos relevante em objetivos exclusivamente nacionais, orientadas que estão pela necessidade de se assegurar a concretização de compromissos universais.

Esse cenário também expõe uma nova realidade para a arquitetura das relações de poder a partir de padrões de governança tipicamente associados à forma de se atingir objetivos globais que não podem ser alcançados exclusivamente por uma atuação apenas nacional, ou ainda, pela iniciativa de organismos internacionais. Até mesmo o papel das Nações Unidas nessa nova perspectiva de governança ambiental global (ainda de contornos mal definidos) deve ser repensado. ${ }^{14}$

Compromissos como os que se relacionam ao objetivo de assegurar processos eficazes para a adaptação perante os efeitos das mudanças climáticas globais expõem uma preocupação que se vincula ao interesse de toda a humanidade, diante da ameaça real de degradação de sua existência. Entretanto, tais objetivos só podem ser atingidos pela conjugação de estruturas institucionais capazes de se comunicar e interagir entre si, o que só se afigura possível quando existe verdadeira cooperação entre os Estados.

A construção de semelhante arquitetura não resulta da ação exclusiva de instrumentos internacionais e de suas instituições, e muito menos da atuação dos Estados 
segundo sua própria pauta de prioridades e projetos de desenvolvimento, mas sim da realização de semelhantes objetivos pelos Estados, e no plano de decisões públicas que são tomadas no âmbito e na forma dos próprios arranjos institucionais nacionais. Trata-se da exposição de um arranjo que tende a priorizar um modelo pelo qual - por meio de escolhas nacionais, comprometidas com compromissos universais -, seja possível conceber e assegurar a realização de objetivos comunitários. Entretanto, isso não decorre necessariamente de um processo de internacionalização das ordens nacionais, senão de um extenso e mais profundo processo de transformação da cultura constitucional, que, por sua vez, define o projeto de sociedade que se pretende viabilizar ou que deve ser viabilizado pelas formas políticas e jurídicas (Häberle, 2000, p. 36-39).

Situada a questão nesses termos, é possível reconhecer que ao Estado e a cada um de nós foi atribuído, pela ordem constitucional atual, um conjunto de deveres perante a humanidade. Esses deveres resultam em consequências que não conhecem limites geográficos ou fronteiras políticas, muito embora ainda decorram de decisões governamentais certamente influenciadas por fatores menos jurídicos que políticos, especialmente os de índole econômica.

É premente que se saiba que os Estados nacionais são agora formações influenciadas e integradas na estrutura de uma ordem jurídica que deixa de ser nacional, e que também não pode ser compreendida como internacional, senão como uma ordem verdadeiramente global. Esta tem sua organização baseada em uma estrutura de redes, que não contempla a autonomia de padrões, referências morais ou culturais e procura atingir seus objetivos a partir da consideração das contradições, das divergências e das diferenças (Dupuy, 1989, p. 115; e Mazzuoli, 2010, p. 130-134).

Nesse contexto, passa a ser dever dos Estados para com a humanidade a cooperação internacional em matéria ambiental, para a qual - nos termos do artigo 78 da Lei dos Crimes Ambientais - deve ser mantido um "sistema de comunicações apto a facilitar o intercâmbio rápido e seguro de informações com órgãos de outros países". O chamado "dever de informar", previsto no artigo 78 citado, é reflexo do impacto dos documentos internacionais no direito brasileiro, haja vista já ter sido previsto no Princípio 20 da Declaração de Estocolmo de 1972, nestes termos:

Deve ser fomentada, em todos os países, especialmente naqueles em desenvolvimento, a investigação científica e medidas desenvolvimentistas, no sentido dos problemas ambientais, tanto nacionais como multinacionais.

A este respeito, o livre intercâmbio de informação e de experiências científicas atualizadas deve constituir objeto de apoio e de assistência, a fim de facilitar a solução dos problemas ambientais; as tecnologias ambientais devem ser postas à disposição dos países em desenvolvimento, em condições que favoreçam sua ampla difusão, sem que constituam carga econômica excessiva para esses países. 
Também na conferência do Rio de Janeiro o tema veio à tona, quando então se deixou expresso nos Princípios 18 e 19 da Declaração sobre Meio Ambiente e Desenvolvimento, o seguinte:

Princípio 18. Os Estados notificarão imediatamente outros Estados acerca de desastres naturais ou outras situações de emergência que possam vir a provocar súbitos efeitos prejudiciais sobre o meio ambiente destes últimos. Todos os esforços serão envidados pela comunidade internacional para ajudar os Estados afetados.

Princípio 19. Os Estados fornecerão, oportunamente, aos Estados potencialmente afetados, notificação prévia e informações relevantes acerca de atividades que possam vir a ter considerável impacto transfronteiriço negativo sobre o meio ambiente, e se consultarão com estes tão logo seja possível e de boa-fé.

Todos esses princípios, que serviram de base para que o legislador brasileiro implementasse entre nós o chamado "dever de informar", traduzem a tônica do Direito Internacional Público contemporâneo em sua vertente ambiental, que é a conjugação de esforços (não só dos Estados, mas de toda a sociedade internacional) para a conscientização ambiental em dimensões globais (Milaré, 2009, p. 1230).

\section{Proteção penal do meio ambiente no contexto de uma cultura GLOBAL DE ACESSO À INFORMAÇÃO: O TRIPÉ DE AARHUS}

Muito embora já fosse possível identificar em momento anterior à década de 1970 a proliferação de normas convencionais com temática ambiental, cujo objeto consistia na proteção de determinados espaços, bens ou elementos naturais, tem-se como certo que a sua verdadeira evolução deu-se apenas a partir da aprovação da Declaração de Estocolmo, na Conferência das Nações Unidas sobre Meio Ambiente Humano de 1972, ocasião em que foi possível viabilizar a organização da estrutura e dos processos de decisão do que se convencionaria a apresentar como um Direito Internacional do Meio Ambiente. A partir da Declaração de Estocolmo de 1972, a estrutura do Direito Internacional do Meio Ambiente seria então reconhecida como baseada em uma lógica de balanceamento e de limitação mútua e recíproca dos direitos de soberania dos Estados (Brunnée, 2008, p. 42).

Embora a literatura internacional ainda não tenha reconhecido (ao menos consensualmente) que o conjunto de seus 26 princípios exponha normas capazes de produzir efeito imperativo (jus cogens) ou direto (hard law) sobre as ordens jurídicas nacionais, ou que tenham integrado o conjunto de normas de um direito costumeiro, 
essa circunstância, conforme salienta Jutta Brunnée (2008, p. 60-61), não implica diminuir sua importância ou seu valor normativo para a organização de um Direito Internacional do Meio Ambiente.

Embora não se lhe reconheça a condição de norma vinculante, o fato de não se atribuir à Declaração a condição de hard law não gera consequências de maior relevância, uma vez que, como destaca Brunnée, a resolução dos conflitos internacionais em matéria ambiental não depende, em geral e exclusivamente, da aplicação direta de normas de tratados ou de convenções multilaterais, além de ser possível verificar que a natureza principiológica das normas de maior importância desempenha relevante influência na organização das experiências normativas nacionais, e também condiciona e orienta a aplicação do Direito nacional, mesmo naquelas ordens que não reconhecem o caráter de direito costumeiro à maior parte dos princípios decorrentes, seja da Declaração de Estocolmo, seja de outros instrumentos de igual valor (Brunnée, 2008, p. 61).

Essa arquitetura pode ser justificada porque em uma ordem jurídica baseada em relações de poder (cujo exercício demanda uma maior horizontalização) o valor normativo e a influência exercida pelo texto das normas e instrumentos de Direito, admitidos às vezes como costume ou como soft law, não mais dependem da consideração de relações jurídicas de hierarquia (Brunnée, 2008, p. 61). Em outras palavras, no que tange ao Direito Internacional do Meio Ambiente o que se presencia é uma conjugação cada vez maior de normas (que "dialogam", para falar como Erik Jayme) ${ }^{15}$ que não dependem, para sua efetividade, de um status ou posição hierárquica dentro de determinado sistema (Bodansky, 1995, p. 3-119).

Sob semelhante perspectiva, ao contrário do que se poderia supor, a proliferação de normas de soft law, que veiculam princípios como o que são analisados nesta seção, o da cooperação entre os Estados, não mitiga, senão expande, a capacidade de influência do Direito Internacional do Meio Ambiente, que se dá, entretanto, sob a forma de relações jurídicas de qualidade distinta daquelas associadas à aplicação das normas de hard law (Brunnée, 2008, p. 61).

Ao admitir a complexidade dos processos que permeiam as relações internacionais contemporâneas e que a dependência de modelos de hierarquização diminui ao mesmo tempo em que se assiste à projeção das relações de poder horizontais, Brunnée (2008, p. 61) salienta que a adoção de acordos ambientais multilaterais não representa mais do que o começo, e não mais o fim, dos processos normativos internacionais.

Uma vez que os processos pelos quais as normas de Direito Internacional do Meio Ambiente que influenciam as relações jurídicas são horizontais, substituindo padrões baseados em relações de hierarquia, é possível reconhecer que nenhum valor teria, neste momento, um dissídio que tivesse por objeto a determinação da natureza vinculante de tais normas (Bodansky, 1995, p. 106-107).

Fixada a abordagem que se pretende vincular à investigação sobre o valor de um dos princípios do Direito Internacional do Meio Ambiente, a saber, o da cooperação, 
e levando-se em consideração a referência da Declaração de Estocolmo de 1972, é importante salientar que a sua aplicação tem condições de expor uma forte vinculação com o Princípio 21 do mesmo texto, que evidencia a soberania dos Estados sobre os seus recursos naturais, condicionada ao dever de não produzir danos a eles (Brunnee, 2008, p. 61; Bodansky, 1995, p. 114-116).

A partir do momento em que foi possível propor a proteção do meio ambiente como parte de um conjunto de valores universais representativos de um consenso global mínimo, e também reconhecer que a degradação dos recursos naturais deixou de apresentar-se como questão sujeita à reserva de decisão soberana (ou domínio reservado) dos Estados, ${ }^{16}$ o dever de cooperação (relativamente comum nos acordos internacionais em geral) ganhou uma ênfase reforçada nos instrumentos específicos de natureza ambiental. ${ }^{17}$

Se os Estados possuem sua soberania condicionada por um imperativo de proteção do meio ambiente, que por sua vez se reflete por meio do dever de se prevenir danos aos recursos naturais, o reconhecimento de que as ameaças não se restringem aos efeitos de decisões nacionais implica admitir que o exercício da soberania pelos Estados depende, necessariamente, da concretização de um imperativo de cooperação para o fim de se assegurar, de forma duradoura, a continuidade no acesso aos recursos, ao mesmo tempo em que se viabiliza a proteção de todas as formas de vida, presentes e futuras.

Sem cooperação não se verifica possível o exercício pleno das prerrogativas da soberania pelos Estados, em uma realidade em que as ameaças são globais e constituem o resultado de escolhas e da acumulação de efeitos que não necessariamente têm origem no plano das decisões, das instituições e dos padrões de proteção admitidos por um Estado nacional.

Contextualizando essa análise em relação ao objeto específico deste artigo, não se poderia subtrair da observação do jurista nacional o fato de a Lei 9.605/1998 representar uma manifestação objetiva que se integra ao mesmo arranjo das relações de poder que se desenvolvem em escala não mais internacional, senão global, de valorização da pessoa e do meio ambiente, como elemento determinante para que uma realidade digna (na qual todos possam desfrutar de qualidade de vida) possa ser atingida.

O texto da Lei 9.605, de 12 de fevereiro de 1998, ainda que involuntariamente, integra-se com perfeição no contexto de uma cultura global influenciada por uma sociedade da informação ambiental, inaugurada naquele mesmo ano, com a adoção no âmbito das Nações Unidas da "Convenção sobre Acesso à Informação, Participação do Público no Processo de Tomada de Decisão e Acesso à Justiça em Matéria de Ambiente”, também conhecida como a Convenção de Aarhus. ${ }^{18}$

A Convenção - tida como o projeto mais ambicioso em matéria de democracia ambiental já realizado pela ONU - reconhece desde o seu preâmbulo a necessidade de proteger, preservar e melhorar o estado do ambiente e de assegurar um desenvolvimento sustentável e respeitador do ambiente, e que a proteção adequada do ambiente 
é essencial para o bem-estar dos indivíduos e a satisfação dos direitos humanos fundamentais, incluindo o próprio direito à vida. Reconhece ainda que todos os indivíduos têm o direito de viver num ambiente propício à sua saúde e bem-estar, e o dever, quer individualmente, quer em associação com outros indivíduos, de proteger e melhorar o ambiente em benefício das gerações presentes e futuras.

Os propósitos da Convenção (que já fazem parte do seu próprio título) vêm expressos no seu artigo $1^{\circ}$, assim redigido:

Com o objetivo de contribuir para a proteção do direito de todos os indivíduos, das gerações presentes e futuras, a viver num ambiente propício à sua saúde e bem-estar, cada Parte garantirá a concessão dos direitos de acesso à informação, à participação do público no processo de tomada de decisões e à justiça no domínio do ambiente, em conformidade com o disposto na presente Convenção.

Celebrada no contexto europeu e fortemente influenciada pelas mudanças que a Europa tem passado nos últimos anos, a Convenção de Aarhus implementa o compromisso dos países europeus de garantir aos cidadãos (nacionais ou não dos seus Estados partes) o acesso à informação, a participação no processo de tomada de decisões e o acesso à justiça no domínio do ambiente, reconhecendo que nesse domínio a melhoria do acesso à informação e da participação pública no processo de tomada de decisões aumenta a qualidade das decisões e contribui para a sensibilização do próprio público para as questões ambientais, permitindo-lhe manifestar as suas preocupações às autoridades públicas sobre essas questões.

Outra importante contribuição da Convenção de Aarhus foi ter aumentado a responsabilidade e a transparência no processo de tomada de decisões, especialmente nos setores de governança, que devem então passar a dar conhecimento ao público dos procedimentos (quaisquer procedimentos) adotados ou a serem adotados sobre as questões ambientais (Pallemaerts, 2004, p. 17-19).

Conquanto ainda não aplicada ao Brasil, ${ }^{19}$ a Convenção de Aarhus serve ao nosso país como paradigma e referencial ético no que toca à cooperação internacional para a proteção do meio ambiente, na medida em que consagra aos cidadãos o acesso à informação, a participação na tomada de decisões e o ingresso à justiça em matéria ambiental. ${ }^{20}$

O interesse especial que se dedica à Convenção reside na abordagem diferenciada proposta ao tema da cooperação, ao expô-lo por meio do que se pode chamar “tripé de Aarhus”. Este se encontra baseado na vinculação entre os elementos informação, participação pública nos processos de tomada de decisões, e acesso à justiça, como pressupostos indispensáveis para o desenvolvimento de um novo ambiente cultural: o de uma sociedade da informação ambiental. ${ }^{21}$ 
Embora não seja indiferente à sociedade internacional a consideração de deveres estatais dedicados à informação e à cooperação em semelhante domínio, seria possível sugerir que a afirmação de uma cultura internacional (e, por que não, global) de informação ambiental só teve origem com o texto da referida Convenção, em 1998.

O tripé de Aarhus - baseado no trinômio informação, participação pública nos processos de decisão, e acesso à justiça - constitui parte integrante do Direito Internacional do Meio Ambiente contemporâneo, além de transpor que os limites de consensos regionais sobre como o meio ambiente deve ser protegido pelos Estados.

Nos termos da Convenção (arts. $4^{\circ}$ a $9^{\circ}$ ), esse tripé sustenta basicamente os seguintes direitos:

- de ter o público em geral o acesso à informação que desejar, incluindo o direito de ter cópias da documentação que contém a informação solicitada:

(a) sem que seja necessário declarar um interesse na questão; (b) na forma solicitada, a menos que: i) seja razoável que a autoridade pública apresente a informação de outra forma; nesse caso, devem ser expostas as razões que o justificam; ou ii) a informação já esteja disponível ao público de outra forma (art. $4^{\circ}, \S 1^{\circ}$. Tal informação deve ser prestada de forma rápida, o mais tardar no prazo de um mês a contar da apresentação do pedido, a menos que o volume e a complexidade da informação justifiquem um prolongamento deste prazo até dois meses após a apresentação do pedido, devendo o requerente ser informado do prolongamento do prazo, bem como das razões que o justificam $\left(\right.$ art. $4^{\circ}, \S 2^{\circ}$ );

- de ser o público envolvido informado de forma adequada na fase inicial de um processo de tomada de decisões em matéria ambiental, por meio de aviso público ou individualmente, designadamente: (a) da atividade proposta e do pedido relativamente ao qual será tomada uma decisão; (b) da natureza das eventuais decisões ou do projeto de decisão; (c) da autoridade pública responsável pela adoção da decisão; (d) do procedimento previsto, incluindo como e quando podem ser comunicadas: i) as informações sobre o início do processo; ii) as informações sobre as possibilidades de participação do público; iii) as informações sobre o momento e local de realização das audições públicas previstas; iv) a indicação da autoridade pública junto da qual seja possível obter a informação relevante e à qual esta informação tenha sido confiada para exame pelo público; v) a indicação da autoridade pública ou qualquer outro órgão oficial para o qual possam ser enviados comentários ou questões, assim como o prazo de apresentação desses mesmos comentários ou questões; e vi) a indicação da informação ambiental disponível relevante para a atividade proposta; e ainda (e) do fato de a 
atividade estar sujeita a um procedimento transfronteiras de avaliação de impacto ambiental $\left(\operatorname{arts} .6^{\circ}, 2^{\circ}\right)$;

- de ser garantido, em conformidade com o disposto na legislação nacional de cada Estado-parte, o direito de se interpor recurso junto aos tribunais, ou de outro órgão independente e imparcial instituído por lei, a qualquer pessoa que considere que o pedido de informações por si apresentado nos termos do disposto no artigo $4^{\circ}$ foi ignorado, indevidamente recusado, no todo ou em parte, objeto de uma resposta incorreta, ou que não tenha recebido um tratamento consentâneo com o disposto no mesmo artigo $\left(\operatorname{art} .9^{\circ}\right)$.

Apesar de se tratar de um acordo inicialmente regional em matéria ambiental, pode-se dizer que os princípios que provêm de Aarhus têm conotação global, notadamente pelo fato de versar um tema de interesse de toda a sociedade internacional, já delineado no Princípio 10 da Declaração do Rio de Janeiro sobre Meio Ambiente e Desenvolvimento de 1992. Em outras palavras, ao abrir aos cidadãos o acesso à informação mantida por autoridades públicas, a Convenção de Aarhus dá um passo importante em termos de superação da democracia formal pela democracia substancial. ${ }^{22}$ Além do mais, ao permitir a Convenção o ingresso de "qualquer outro Estado (...) que seja membro das Nações Unidas (...) após aprovação em Reunião das Partes" (art. 19, $\S 3^{\circ}$ ), está ela contribuindo para catalisar os esforços da sociedade internacional rumo àquilo que se pode chamar de "controle externo" das atividades estatais no que tange à proteção efetiva do meio ambiente em escala global.

Como se percebe, o que se está a assistir neste momento é o desenvolvimento de um movimento contemporâneo em que a ordem jurídica nacional está integrada em uma "cultura global” aberta aos direitos ambientais, e ao reforço da proteção de uma referência mais alargada de dignidade de vida, que também agrega os deveres de conservação e melhoria da qualidade dos recursos naturais. A Convenção de Aarhus enfatiza e representa o marco referencial dessa cultura e influencia experiências como a brasileira, na qual políticas públicas ambientais, gerais e setoriais, encontram-se vinculadas à imagem de um Estado ambiental, visando contribuir para o desenvolvimento de um projeto coletivo e comunitário de um futuro no qual impere o primado da dignidade da vida.

Por esse motivo, movimentos da sociedade civil brasileira têm manifestado interesse em que o nosso governo ratifique a Convenção o mais prontamente possível, especialmente por considerar a importância da participação pública nas decisões ambientais com amplo acesso à informação ambiental e, ainda, a necessidade de ser incentivada a participação popular e das organizações não governamentais como corolário do Estado Democrático e Ecológico de Direito. ${ }^{23}$ 
A integração da Lei 9.605/1998 nessa cultura de valorização (e proteção) de todas as formas de vida representa uma manifestação objetiva da organização dos instrumentos vinculados a um Direito Ambiental de segunda geração. ${ }^{24}$ Aqueles devem ser capazes de reduzir os riscos existenciais de conteúdo diferenciado, sob uma perspectiva igualmente diferenciada, para as tarefas e objetivos de uma ordem ou experiência jurídica.

Em uma realidade de problemas ambientais de segunda geração, que requerem o desenvolvimento de um Direito Ambiental de segunda geração, a Convenção de Aarhus propõe um mecanismo complexo baseado na interação entre instrumentos capazes de favorecer a produção e o acesso à informação, a participação e a influência do público nos processos de decisão ambientalmente relevantes, bem como o acesso aos sistemas de justiça, admitindo-se a proteção do meio ambiente e da qualidade de vida como valores universais, cuja concretização deve atender às especificidades das experiências jurídicas nacionais. Estas estão e serão substancial e formalmente condicionadas por tal cultura universal, que vincula a proteção dos direitos humanos e a proteção dos direitos ambientais como partes de um processo global de reafirmação e proteção dos valores de uma sociedade guiada pela dignidade como primado para a existência da humanidade.

Nesse contexto, o acesso à informação sobre as fontes poluentes e seus efeitos também constitui um pressuposto para o exercício livre de um determinado projeto existencial. Não é possível realizar escolhas livres ou assegurar o livre desenvolvimento da personalidade em uma realidade na qual não se assegure que a comunidade possa ter acesso ao conhecimento disponível sobre planos, atividades e processos que tenham condições de comprometer esses projetos de vida, ou uma pluralidade de projetos existenciais, culturais, sociais e economicamente diferenciados. O acesso à informação é, por assim dizer, o corolário dos princípios da dignidade humana (art. $1^{\circ}$, III, da CF/1988) e da prevalência dos direitos humanos (art. $4^{\circ}$, II, da CF/1988), garantidos pelo texto constitucional brasileiro como pilares fundamentais da nossa ordem jurídica.

A garantia de acesso à informação e de intervenção nos processos de formação das decisões constituem, desse modo, elementos indispensáveis para o fim de se viabilizar padrões mais elevados de qualidade de vida; padrões que sejam o resultado de escolhas públicas e privadas, individuais ou coletivas, e que são, e devem ser sempre, escolhas bem informadas, segundo o estado do conhecimento disponível.

\section{O PRINCÍPIO DA PRECAUÇÃO EM UMA CULTURA GLOBAL DE ACESSO À INFORMAÇÃO AMBIENTAL}

Em uma cultura global que enfatiza o acesso à informação, influenciada pelo tripé de Aarhus, a atividade institucional de gestão dos riscos depende diretamente da eficiência na organização de instrumentos e processos que permitam o acesso, o conhecimento e a 
tomada de posição perante as diversas espécies de conflitos ambientais. Esses aspectos recuperam o sentido republicano de participação do público e enfatizam a dimensão da informação que permite assegurar condições para que efetivamente todos os aspectos de pertinência sejam avaliados e levados em consideração para a seleção da melhor opção, de acordo, principalmente, com a avaliação da capacidade e qualidade da ofensividade dos prováveis efeitos diretos sobre o ambiente, importando supor especialmente a necessidade de que os processos de avaliação dos impactos considerem, progressivamente, questões em longo prazo. ${ }^{25}$

A segurança técnica e científica já não pode justificar a organização dos objetivos de um sistema jurídico de proteção do ambiente em contextos sociais, nos quais se desenvolvem relações que impõem como problema a necessidade de estabelecer condições de acesso à informação suficiente e adequada para a decisão, mesmo quando tais condições não se fazem presentes.

As alternativas de regulação dos riscos dependem cada vez mais da capacidade de desenvolvimento de exigentes condições de democracia ambiental nos processos de decisão, como meio necessário para a gestão dos riscos oriundos de situações de indisponibilidade da informação.

O reconhecimento, pelo Direito Ambiental, da insuficiência, da incompletude e, até mesmo, da inadequação dos modelos de gestão científica dos riscos é pressuposto fundamental para a superação teórica de propostas regulatórias tipicamente associadas ao ineficaz modelo de ecologia cosmética.

O desenvolvimento do significado jurídico do princípio da precaução expressa com notável representatividade o particular quadro de modificação dessas alternativas de regulação, evidenciando definitivamente a falência institucional dos objetivos de segurança. O conteúdo jurídico do princípio da precaução procura substituir modelos de decisão fundados na segurança técnica ou científica, privilegiando modelos que garantam um estado de segurança ética. ${ }^{26}$

A regulação jurídica do ambiente deve organizar os processos de gestão de riscos minimamente conhecidos, ou absolutamente desconhecidos, mediante a correta compreensão da trilogia representativa dos problemas tipicamente associados à eficácia da proteção jurídica das futuras gerações, relacionando tempo, conhecimento e informação em processos decididos mediante a intervenção de instrumentos que permitam ponderar, avaliar e julgar adequadamente os elementos dessa tríade.

Essa é a razão pela qual ganha destaque a caracterização das específicas condições de aplicação do princípio, que é, nesse contexto, um instrumento imprescindível na ordenação do ponto ótimo de proteção do ambiente em sociedades cuja característica fundamental reside em não oferecer as condições de segurança técnica, científica e informativa necessárias para esses processos de tomada de decisão. ${ }^{27}$

O desenvolvimento da temática da gestão dos riscos indica caminhos para a modificação das ações das instituições, mediante a proposição de elementos que procuram 
permitir o desenvolvimento dos melhores pontos de consensos democráticos na gestão da informação nos processos de decisão sobre esses riscos, podendo ser enumerados os seguintes: (a) necessidade de participação popular; (b) desenvolvimento de novas metodologias para a análise dos riscos, podendo ser proposta uma sequência de objetivos que importam (i) a redução dos riscos (prevenção), (ii) a mitigação dos efeitos prejudiciais oriundos de eventual ação de risco e (iii) a implementação de estratégias de proteção para riscos imprevisíveis ou para os casos em que a prevenção ou a mitigação falharam; (c) obediência à sequência de identificação (determinação), gestão e comunicação dos riscos ${ }^{28}$ (d) submissão da percepção dos riscos à avaliação pública (desenvolvimento das noções de responsability e accountability); (e) desenvolvimento de novas instituições de elevada qualidade democrática (comitês, conselhos, agências, etc.); e (f) compreensão diferenciada dos processos de análise dos riscos. ${ }^{29}$

A gestão da informação especializada, precária, insuficiente, inacessível ou mesmo inexistente, supõe um modelo de gestão que, conquanto preveja sequências de identificação, avaliação, gestão propriamente dita e monitoramento, privilegie o momento da comunicação dos riscos, aspecto que permite afirmar que esse processo deve considerar novos parâmetros de orientação das decisões e metodologias de avaliação dos riscos, que poderiam ser traçados assim: (a) os riscos devem ser selecionados em razão da sua qualidade (os riscos de elevada complexidade e as incertezas devem ser privilegiados como objeto de análise, buscando sua diminuição e controle); (b) a informação e a comunicação devem preferir a quantificação; ${ }^{30}$ e (c) o risco deve impor como método de trabalho a transparência e a visibilidade da organização. ${ }^{31}$

Nesse sentido, como já afirmado, características diferenciadas precisam ser desenvolvidas nos processos de análises dos riscos, privilegiando os seguintes aspectos: (a) a determinação e avaliação dos riscos não podem ser dissociadas da gestão desses riscos, sendo que os julgamentos devem se realizados em ambos os momentos; ${ }^{32}$ (b) deve-se considerar que a determinação dos riscos depende também de informações econômicas, valores sociais e sofre a influência de diferentes aspectos culturais; (c) a determinação dos riscos não pode ser cientificamente vinculada, porque deve considerar que a incerteza e a ignorância são obstáculos que nem sempre podem ser superados pela ciência; (d) os processos de tomada de decisão devem considerar que não se pode estabelecer critérios, preferências ou privilégios de ordem absoluta entre valores científicos e políticos para a informação da decisão (as soluções são negociadas e priorizam a busca de consensos bem informados); e (e) as soluções (decisões) sobre problemas que se organizam a partir de bases de risco deverão privilegiar opções que levem em consideração a prevenção e/ou a precaução.

Se pudéssemos estabelecer, portanto, uma espécie de agenda de ações e aspectos reputados relevantes para a organização da compreensão social e institucional das novas relações de risco, alguns elementos poderiam ser propostos, dentre eles: (a) os riscos não podem ser compreendidos integralmente ou por vezes, minimamente, pela 
ciência; (b) nem sempre os riscos podem ser determinados de forma individualizada, apresentando-se de forma complexa, híbrida e composta, dificultando o desenvolvimento de instrumentos idôneos para a sua especificação; (c) os riscos exigem que sejam consideradas soluções de governabilidade democrática, processos públicos, além de otimização da capacidade de decisão dos cidadãos.

A proposição de alternativas eficientes para os processos de gestão dos riscos, portanto, exige medidas que procurem permitir o acesso do público para a tomada de decisões, tais como a previsão de comitês mistos e transcientíficos, especialmente em relação à gestão da biotecnologia e da indústria química, objetivando sempre prevenir e/ou minimizar os indesejáveis efeitos da falha técnica, optando por submeter os processos de decisão ao controle público.

Essa opção está bem clara no artigo $6^{\circ}, \S 4^{\circ}$, da Convenção de Aarhus, que entende que as partes estão obrigadas a adotar todas as medidas para que a participação do público comece desde o início do procedimento, quando todas as opções e soluções ainda são possíveis, e especialmente quando o público ainda pode exercer uma influência real. 33

A dimensão das escolhas é enfatizada porque as decisões são geralmente produzidas a partir de processos, e não de forma unilateral, porque o fundamento de sua legitimidade deixa de ser a autoridade, preferindo-se agora a negociação (Ladeur, 2002. p. 21).

$\mathrm{Na}$ gestão dos riscos, as soluções de “concertação” e os modelos de cooperação estão a preferir decisões dependentes de formas de conhecimento cientificamente limitadas (Ladeur, 2002, p. 29-30). Essa é uma alternativa compatível com o atual padrão de regulação dos sistemas jurídicos nas sociedades de risco baseados em uma postura preventiva e no desenvolvimento de ambiciosos programas orientados pelo futuro, definidos essencialmente por conjuntos de ações de prevenção dos riscos (Ladeur, 2002, p. 09).

Pode-se reconhecer com clareza a importância do princípio da precaução que atua de forma prática como instrumento de controle e gestão da informação nos processos de decisão sobre os riscos, uma vez que o efetivo problema proposto pelo princípio é como se deve decidir perante bases informativas de elevado grau de imprevisão e insegurança científica, impondo obrigações de originar decisões, mesmo perante bases cognitivas precárias (Ayala, 2002, p. 230-233).

Tal como já se qualificou outro princípio de grande importância para o próprio Direito ambiental (princípio da proporcionalidade), ${ }^{34}$ o particular contexto de aplicação do princípio da precaução envolve a necessidade de resolução de problemas a partir de bases limitadas de conhecimento, circunstância que enfatiza sua compreensão a partir de uma dimensão programadora, que se concentra em buscar alternativas para se tomar as melhores decisões possíveis, tentando superar os estados de incerteza.

O princípio da precaução vem estabelecer, no domínio da regulação jurídica dos riscos e da proteção jurídica do ambiente, uma autêntica "proibição de non liquet", mesmo perante o conhecimento indisponível, inacessível ou inexistente. ${ }^{35}$ 
Esse problema só pode ser convenientemente equacionado se os modelos especialistas forem substituídos por modelos plurais e abertos a outros valores não propriamente científicos, devendo-se considerar que até mesmo o conhecimento especializado é hoje considerado instável e inseguro. A aplicação do princípio da precaução supõe, portanto, a opção por modelos de "concertação" que relacionem dados científicos a valores plurais e democráticos, revelando que as escolhas também podem ser políticas, mas não apenas políticas, e nunca exclusivamente científicas, afirmação que revela que a ciência e a técnica são apenas realidades parciais no contexto dos processos de decisão sobre os riscos.

Esse parece ser o aspecto inovador introduzido pelo princípio da precaução na diferenciação da qualidade da organização da regulação jurídica do ambiente nas sociedades de risco. O princípio da precaução vem afirmar que mesmo perante a incapacidade da ciência na atividade de originar o conhecimento especializado e sobre as bases informativas necessárias (de que dependeriam, a princípio, as decisões), ainda persiste a obrigação de que o conhecimento seja necessariamente produzido. Ou seja, mesmo que a ciência não tenha conseguido originar o conhecimento, persiste a necessidade de que, de alguma maneira, seja ele realizado. E diante da incapacidade da ciência em fazê-lo, desenvolve-se progressivamente a importância da temática dos vínculos entre democracia e processo, por meio de soluções de "concertação" que permitam, mediante participação pública, acesso e a composição das bases informativas, ${ }^{36}$ fazer a comunicação entre espécies de conhecimento não especializadas, e de natureza eminentemente precária.

A negociação impõe a opção por soluções de gestão dos riscos que busquem executar e concretizar especificamente o sentido jurídico da repartição compartilhada de responsabilidades na proteção do ambiente, na medida em que, ante a inconclusão ou inexistência de informações necessárias para a decisão, busque-se produzir o conhecimento ainda indisponível (Ayala, 2002, p. 232), mediante a organização dos melhores pontos democráticos de consenso que sejam permitidos no caso específico, atingidos sempre que se permita conciliar, no caso concreto, a consideração jurídica da natureza e a proteção dos interesses das futuras gerações.

Essa característica acentua com intensidade a necessidade de se estabelecer, em todos os processos de tomada de decisões, um sentido integral de definição dos objetivos do direito ambiental (Canotilho, 2001, p. 12), e ainda de serem realizadas, na composição dos interesses, ponderações tão completas quanto possíveis, levando em consideração todos os aspectos relevantes e pertinentes à solução da temática decisória. ${ }^{37}$ Essa imposição só é possível mediante processos bem informados e que deem oportunidade para a participação pública e democrática no momento da seleção das escolhas adequadas.

A responsabilidade pela produção do conhecimento e da informação necessária à decisão é, dessa forma, compartilhada entre todos os atores desse processo público, 
enfatizando a dependência da capacidade regulatória do direito ambiental nas sociedades de risco, o desenvolvimento de condições concretas e atuais de solidariedade e, sobretudo, a pluralidade participativa, atributos que, reunidos, qualificam as características fundamentais dos novos contornos de aplicação do princípio da precaução.

\section{O DEVER de COOPERAÇÃO ENTRE EstAdos NA PROTEÇÃo PENAL DO MEIO AMBIENTE}

Já se falou neste artigo que - ao partir de uma cultura de valorização do acesso à informação como elemento indissociável à formação de uma imagem de Estado ambiental e ao desenvolvimento de projetos existenciais individuais e coletivos comprometidos com a qualidade de vida e dos recursos naturais -, o artigo 78 da Lei 9.605/1998 enfatiza um dever de informar, cujo conteúdo se encontra vinculado ao dever geral de cooperação entre os Estados ou com um compromisso político perante a ordem internacional, visando à repartição de responsabilidades para o fim de proteção do meio ambiente.

O referido dispositivo traduz concretamente a manifestação de um princípio de cooperação, tal como descrito pelos instrumentos internacionais de hard law relativos ao tema (em especial, pela Convenção de Aarhus de 1998) e também de soft law sobre meio ambiente (Kiss e Shelton, 2007, p. 102).

No caso brasileiro, verifica-se que em decorrência de um princípio de cooperação é dever do Estado não apenas facilitar o acesso da ação persecutória penal em matéria ambiental com iniciativa externa (cujo procedimento, em se tratando de iniciativas judiciais, vem descrito pelo artigo 77 da Lei 9.605/1998), mas também viabilizar o cumprimento de atos extrajudiciais que devam ser praticados no Brasil no interesse da proteção penal do meio ambiente. Frise-se que nos termos do mesmo artigo 77, apenas a soberania nacional, a manutenção da ordem pública e os bons costumes podem ser elementos capazes de legitimar a recusa do Estado brasileiro em prestar a cooperação pretendida. ${ }^{38}$

O que visou a Lei 9.605/1998 em apreço foi enfatizar que o êxito dos resultados pretendidos e a prática dos atos no Brasil dependerão, necessariamente, da cooperação e do acesso à informação suficiente, o que está em consonância com os princípios maiores decorrentes do Direito Internacional do Meio Ambiente e seus instrumentos de proteção. Por essa razão, integrado na mesma abordagem exposta pela Convenção de Aarhus de 1998, o artigo 78 da Lei propõe que a cooperação em matéria de proteção penal do ambiente não pode obter êxito senão por meio de um dever estatal de aperfeiçoar os sistemas de produção e de aquisição de todas as informações relevantes, que possam permitir e viabilizar a persecução penal ambiental por iniciativa dos países que tenham de fazê-la, a partir dos meios disponíveis no Brasil. 
A referência genérica pouco aperfeiçoa um dever geral de cooperação já presente na relação de instrumentos internacionais de que o Brasil é signatário ou não, e que preveem idêntico objetivo, razão pela qual pouco acrescenta à concretização de um dever de aperfeiçoar e melhorar os níveis de proteção fixados pelas demais normas de proteção do meio ambiente.

De forma distinta da experiência brasileira, a ordem jurídica comunitária tentou implementar, por iniciativa da Comissão da Comunidade Europeia (hoje Comissão da União Europeia) uma proposta de Diretiva visando organizar regras específicas para a cooperação judiciária em tema de proteção penal do ambiente que, entretanto, não foi levada a cabo (Comissão das Comunidades Europeias, 2001).

Por outro lado, o Conselho da Comunidade Europeia (hoje Conselho da União Europeia) propôs regras sobre o tema por meio da Decisão-Quadro 2003/80/JAI, de 27 de janeiro de 2003, tendo por objeto os crimes graves contra o meio ambiente, aqueles capazes de causar prejuízos importantes ao ambiente pela poluição do ar, da água, do solo ou subsolo, e do armazenamento ou eliminação de resíduos ou substâncias análogas.

Convém salientar que essa decisão foi anulada por acórdão do Tribunal de Justiça da União Europeia, de 13 de setembro de 2005, no processo C-176/2003, tendo como partes a Comissão (que apresentou a proposta de Diretiva) e o referido Conselho (responsável pela iniciativa da decisão), sob o fundamento de que a Comissão pode tomar medidas relacionadas com o direito penal dos Estados-membros sempre que a aplicação de sanções penais constitua uma medida indispensável para coibir crimes graves contra o ambiente. Sob essa perspectiva, a competência para a adoção de tais medidas não cumpriria ao Conselho, senão ao Parlamento Europeu.

Embora também não se tenha na experiênica comunitária uma manifestação mais concreta sobre os instrumentos de cooperação em matéria de proteção penal do ambiente, na experiência europeia, assim como na brasileira, foi ao menos enfatizada a necessidade de se ter uma proteção penal do ambiente, bem assim instrumentos para assegurar essa proteção, como condição para a melhoria da qualidade do meio ambiente e da vida de todos os que esse planeta habitam.

\section{Conclusões}

O tema da cooperação internacional encontra na seara ambiental uma profícua área de trabalho, repleta de possibilidades e também desafios. À medida que contribui para a salvaguarda do meio ambiente, faz também operar a difusão da conscientização ambiental, necessária ao esclarecimento de quais direitos se têm (e se poderá ter) nesse domínio.

Mais do que o dever de cooperar, é a obrigação de informar a pedra de toque do sistema contemporâneo das normas (internacionais e internas) de cunho ambiental, 
notadamente das que expressamente garantem o acesso à informação, a participação pública no processo de tomada de decisões e o ingresso dos cidadãos à justiça em matéria ambiental.

Como foi possível perceber pela abordagem desenvolvida neste artigo, a Convenção de Aarhus de 1998 constitui um importante instrumento que influencia e contribui para o aperfeiçoamento de uma cultura universal (ou global) de informação, de participação e de interferência da coletividade nos processos de decisão ambientalmente relevantes.

Em um contexto de proliferação dos riscos ecológicos, a consideração do assim denominado tripé de Aarhus, baseado no trinômio informação, participação pública e acesso à justiça ambiental, apresenta-se como pressuposto indispensável para a formação de uma nova arquitetura para a gestão dos riscos de sociedades complexas.

Tais sociedades nem sempre possuem instituições e instrumentos capazes de assegurar o conhecimento integral sobre os fenômenos e sobre as externalidades ambientais. Mais do que isso, em muitas coletividades sequer existem instrumentos jurídicos para garantir aos interessados o conhecimento de fenômenos ambientalmente relevantes. Em semelhante contexto, uma cultura global de informação e de cooperação e matéria ambiental, favorecida pela consideração do "tripé de Aarhus", teria condições de impedir os deficits de informação mediante sua produção e integração em processos públicos e plurais, nos quais se procuraria fixar conhecimento e informação pela colaboração da sociedade, imbuída em uma lógica de solidariedade e com fundamento em um princípio de imparcialidade.

A investigação demonstrou uma forte aproximação e a compatibilidade da arquitetura normativa exposta pela ordem jurídica brasileira (em especial, pela Lei 9.605/1998) com o modelo definido pela Convenção de Aarhus, que, por sua vez, também favorece a formação e a consolidação de uma cultura global de precaução em matéria ambiental.

Ainda que inicialmente adotada no contexto europeu, a Convenção de Aarhus está aberta à participação de outros Estados (artigo $19, \S 3^{\circ}$ ), podendo então o Brasil figurar como parte. Em nosso país, revela-se dever constitucional da sociedade e do poder público a preservação de um meio ambiente sadio para a presente e para as futuras gerações, o que somente se efetiva quando se tem (na prática) participação pública nas decisões ambientais com amplo acesso à informação ambiental, bem assim das organizações não governamentais.

Com base na obrigação de participação pública e cooperativa na gestão e produção do conhecimento relevante para a decisão - destacando-se, sobretudo, que a informação necessária e adequada é sempre um resultado de ações coordenadas e originárias de obrigações de investigar compartilhadas entre os vários atores participantes -, o enfoque precaucional apresenta-se como o caminho mais seguro (além de mais ético) para a tomada de decisões sobre os novos riscos que se proliferam nas sociedades contemporâneas. 
O princípio da precaução também exerce função angular nessa abordagem, na qualidade de instrumento de gestão da informação, especialmente em contextos de crises, porque propõe alternativas conciliatórias e proporciona o desenvolvimento de consensos democráticos a partir de bases de conhecimento precárias, insuficientes ou, até mesmo, inexistentes.

Tomar decisões sobre tais riscos nas sociedades contemporâneas é e deve ser o resultado de ações de cooperação, coordenação e integração, que se desenvolvem em processos públicos, plurais e participativos, sob as bases de um sistema de gestão cooperativa da informação.

Ficou também demonstrado que uma cultura global de informação e de cooperação em matéria ambiental favorece a formação e a organização de instituições capazes de melhor solucionar os conflitos ambientais, contribuindo para o fortalecimento de uma imagem de Estado ambiental nos planos nacional e internacional. Nesse sentido, a Convenção de Aarhus contribui decisivamente para um processo de universalização de três valores que se manifestam como condições indissociáveis para uma política eficaz em matéria ambiental: (1) a informação; (2) a participação pública; e (3) o acesso à justiça em matéria ambiental.

Sob a perspectiva examinada, e sob a abordagem exposta, tem-se que o direito à informação ambiental, em sintonia com a proteção da participação pública e do acesso à justiça, constitui a chave de uma política ambiental capaz de estabelecer relações dinâmicas de interação e de comunicação com a ordem pública de uma sociedade global, em processos que interessam ao desenvolvimento das condições de vida das gerações futuras e à própria consolidação de um Estado ambiental com feições cada vez mais universais.

Uma cultura global de informação e de cooperação ambiental interessa à proteção da qualidade de vida da presente e das futuras gerações, além disso, ela esboça indícios de que não é excessivo sugerir a consideração de um Estado mundial do ambiente ou de um Estado ambiental global como uma forma diferenciada de realidade política e institucional pela sociedade internacional.

: ARTIGO APROVADO (01/06/2012) : RECEBIDO EM 20/01/2011 


\section{NOTAS}

1 Assim dispõem os artigos referidos: "Art. 77. Resguardados a soberania nacional, a ordem pública e os bons costumes, o Governo brasileiro prestará, no que concerne ao meio ambiente, a necessária cooperação a outro país, sem qualquer ônus, quando solicitado para: I - produção de prova; II - exame de objetos e lugares; III - informações sobre pessoas e coisas; IV - presença temporária da pessoa presa, cujas declarações tenham relevância para a decisão de uma causa; V - outras formas de assistência permitidas pela legislação em vigor ou pelos tratados de que o Brasil seja parte. $\S 1^{\circ} \mathrm{A}$ solicitação de que trata este artigo será dirigida ao Ministério da Justiça, que a remeterá, quando necessário, ao órgão judiciário competente para decidir a seu respeito, ou a encaminhará à autoridade capaz de atendê-la. § $2^{\circ} \mathrm{A}$ solicitação deverá conter: I - o nome e a qualificação da autoridade solicitante; II - o objeto e o motivo de sua formulação; III - a descrição sumária do procedimento em curso no país solicitante; IV - a especificação da assistência solicitada; V - a documentação indispensável ao seu esclarecimento, quando for o caso. Art. 78. Para a consecução dos fins visados nesta Lei e especialmente para a reciprocidade da cooperação internacional, deve ser mantido sistema de comunicações apto a facilitar o intercâmbio rápido e seguro de informações com órgãos de outros países”.

2 Frise-se que neste texto não se tratará de questões propriamente penais ou processuais penais versadas pelos arts. 77 e 78 da Lei dos Crimes Ambientais.

3 Além da citada Lei 9.605/1998, outras normas brasileiras versam o tema da cooperação internacional, a exemplo da Lei 9.613/1998 (Lei de Lavagem de Dinheiro) e da Lei 11.343/2006 (Nova Lei de Drogas).

4 Aprovado pelo Decreto legislativo 333, 24.07.2003 e, após ratificado, promulgado pelo Decreto 5208, de 17.09.2004.

5 Para um estudo mais analítico da proteção internacional do meio ambiente (histórico, fontes e suas relações com a proteção internacional dos direitos humanos) veja-se Mazzuoli (2011, p. 977-1003). Cf. também, Mazzuoli (2004, p. 97-123).

6 Sobre esse status diferenciado dos tratados de direitos humanos na ordem jurídica brasileira, v. Mazzuoli, 2011 (p. 817-847). Cf. também, Mazzuoli, 2010 (p. 185-186).

7 Sobre o assunto, v. ainda Soares (1994, p. 93-139).

8 Para um estudo detalhado desse princípio, v. Sarlet (2004, especialmente p. 29-75).

9 Para um panorama mais analítico das experiências referidas, v. Ayala (2011, p. 173-230).

10 Sobre o tema, v. Díaz Revorio (1997).

11 Saliente-se que a tarefa referida já se encontrava desvinculada de uma perspectiva utilitária de otimização das pretensões e expectativas individuais, uma vez que já não é recente na dogmática pública a afirmação de um sentido social, cuja expressão se refletia em objetivos de segurança social à coletividade, próprios de um Estado social de direito. Este, por sua vez, representa uma perspectiva de proteção que é adicionada (não exprimindo, portanto, uma noção de superposição ou de substituição de projetos políticos por projetos autônomos) àquela primeira, própria de uma orientação liberal para o exercício do poder político, cuja expressão também se refletia na definição do conteúdo dos direitos humanos e fundamentais. Essa definição priorizava a garantia do livre desenvolvimento da personalidade, para a qual era fundamental o livre exercício das liberdades econômicas e civis.

12 Em vigor no Brasil desde 24.04.1992, na forma de seu art. 27, § 2º (cf. Dec. 591, de 06.07.1992).

13 A referência aos riscos de segunda geração tem o mesmo sentido utilizado por Canotilho em um ensaio (v. Canotilho, 2009, p. 22).

14 V. Andresen, Global environmental governance: UN fragmentation and co-ordination (in: Stokke et al., 2001. p. 19-26). 
15 Jayme (1995, p. 251-259). Para o desenvolvimento da concepção dialógica de Erik Jayme, v. Mazzuoli (2010, p. 129-177).

16 Para críticas à teoria do domínio reservado, v. Cançado Trindade (1991, p. 5SS).

17 A proteção do meio ambiente, ou em sua abordagem restritiva, dos recursos naturais, representa, antes de tudo, um problema de natureza global, relacionado a efeitos transfronteiriços e cuja solução demanda o reconhecimento de uma relação indissociável entre as decisões sobre o meio ambiente e as decisões sobre o desenvolvimento, razão pela qual a cooperação constitui dever indissociável dos Estados na sociedade internacional. Conforme explica Sands, a obrigação geral de cooperar está relacionada, basicamente, à implementação dos objetivos dos tratados e convenções, além de outros objetivos mais específicos, como assegurar o acesso à informação e a participação nos processos de tomada de decisão. Estão compreendidas nessa abordagem normas que prevejam estudos de impacto ambiental, assegurando que Estados vizinhos recebam informações suficientes, compreendendo deveres de troca de informação, consultas e notificação, implementação conjunta de padrões de proteção, acesso à informação emergencial, entre outras (cf. Sands, 2003, p. 250).

18 A Convenção foi adotada em Aarhus (Dinamarca) em 25.06.1998, por ocasião da IV Conferência Ministerial “Ambiente para a Europa”, tendo entrado em vigor em 30.10.2001, e celebrada pela então Comunidade Europeia (hoje, União Europeia) em 17.02.2005, por meio da decisão 2005/370/CE. O Secretariado da Convenção funciona junto à ONU, em Genebra (Suíça). Para o texto da Convenção, v. United Nations Treaty Series, vol. 2161, p. 447, bem como texto disponível em: www.unece.org/env/pp/documents/cep43e.pdf. Para o status das ratificações, consultar: www.unece.org/env/pp/ratification.htm.

19 Apesar de a Convenção ter sido inicialmente adotada por países europeus, há nela permissão para que outros Estados adiram ao texto, se autorizados pela Reunião das Partes (Meeting of the Parties, MOP), como expressamente prevê o seu art. 19.

20 Frise-se que a Convenção de Aarhus, por versar tema ambiental, enquadra-se na categoria dos tratados de direitos humanos lato sensu. Assim sendo, sua incorporação ao Direito brasileiro (se e quando ocorrer) dar-se-á com status hierárquico privilegiado (que na nossa concepção é o status de "norma constitucional”). Não é neste artigo, porém, o lugar de se versar o tema da hierarquia dos tratados sobre meio ambiente na ordem jurídica brasileira. Sobre o assunto, v. Mazzuoli (2005, p. 331-349).

21 No Brasil, a Lei 10.650, de 16.04.2003, no seu art. $2^{\circ}$ dispõe sobre o acesso público aos dados e informações existentes nos órgãos e entidades integrantes do Sistema Nacional do Meio Ambiente, Sisnama (instituído pela Lei 6.938, de 31.08.1981).

22 Sobre a superação da democracia formal pela democracia substancial, v. Gomes e Mazzuoli (2010, p. $58-60$.

23 Cf. Congresso Internacional: o novo direito ambiental por Michel Prieur. Carta de São Paulo 2: sobre a Convenção de Aarhus (Revista Internacional de Direito e Cidadania 8/209-210), que contou com a participação dos conferencistas Michel Prieur, professor doutor honorário da Faculdade de Direito e Ciências Econômicas de Limoges (França) e presidente do Centro Internacional de Direito Comparado do Meio Ambiente; Paulo Affonso Leme Machado, jurista e professor doutor de Direito Ambiental na Faculdade de Direito, Unimep; e dos debatedores Álvaro Luiz Valery Mirra, juiz no Estado de São Paulo; Flavia Frangetto, advogada e presidente do Instituto Brasileiro de Direito Ambiental; Consuelo Moromizato Yoshida, desembargadora federal no Tribunal Regional Federal, $3^{a}$ reg.; Solange Teles da Silva, advogada e professora de Direito Ambiental; Regina Helena Fortes Furtado, promotora de justiça na Comarca de Limeira, SP; Walter Claudius Rothenburg, procurador regional da República, $3^{\text {a }}$ região.

24 Sobre o tema, a primeira abordagem na literatura jurídica nacional pode ser conferida em: Ayala (2010, p. 11-41).

25 Para uma ampla visão de contraste sobre a qualidade e eficiência dos processos de avaliação dos efeitos negativos sobre o ambiente na experiência alemã, norte-americana e europeia, a partir dos processos de avaliação de contratos, v. Ladeur e Prelle (2001, p. 185-198). 
26 V. Comitê Econômico e Social Europeu. Parecer do Comitê Econômico e Social sobre "O recurso ao princípio de precaução" (Parecer de iniciativa), p. 3.

27 Sobre a análise das especificidades e condições de aplicação do princípio da precaução perante bases informativas precárias, v. Ayala (2002, p. 183-218).

28 V. Comitê Econômico e Social Europeu (op. cit., p. 1).

29 De acordo com a posição afirmada na União Europeia, a análise dos riscos não pode privilegiar a quantificação dos riscos (análises de relação custo-benefício); deve inserir-se em dispositivos de negociação social, em que sua função é instruir as bases do diálogo (idem, ibidem, p. 4).

30 Idem, ibidem.

31 Sobre a importância da necessidade de participação na fase de avaliação dos riscos, v. Petts (2002, p. 10-14).

32 Essa perspectiva integrada entre a avaliação e a gestão dos riscos é afirmada pelo Comitê Econômico e Social Europeu como condição necessária para a própria aplicação do princípio da precaução, que exige primeiro uma avaliação objetiva dos riscos - pautada em dispositivos de negociação social -, para a sequência da gestão desses riscos, por meio de procedimentos nos quais as decisões são tomadas de forma transparente e acessível (cf. Parecer do Comitê Econômico e Social sobre "O recurso ao princípio de precaução", p. 7). Sobre o tema, v. ainda Bro-Rasmussen (1999, p. 190).

33 Veja-se o dispositivo: "Cada Parte velará pela participação do público o mais cedo possível no processo, quando todas as opções estiverem em aberto e possa haver uma participação efetiva do público”.

34 V. Engel (2001, p. 4).

35 Pensamos ser possível reconhecer essa particular proibição de non liquet relacionada à indisponibilidade do conhecimento, especialmente quando se confere da posição do Comitê Econômico e Social Europeu que o princípio da precaução também tem por conteúdo uma obrigação de desenvolver o conhecimento (cf. Parecer do Comitê Econômico e Social sobre "O recurso ao princípio de precaução", p. 4).

36 Sobre as relações estabelecidas entre tempo e processo, a partir de bases democráticas de participação pública nos procedimentos ambientais, v. Ayala (2002, p. 658-662).

37 A técnica da consideração de todos os interesses relevantes no processo de balanceamento ou ponderação é lembrada por Ladeur (2002, p. 18). Canotilho faz referência à necessidade de realizar ponderações entre direitos e interesses sob uma perspectiva multimetática de compreensão do ambiente (2001, p. 12).

38 Veja-se a redação do dispositivo: "Resguardados a soberania nacional, a ordem pública e os bons costumes, o Governo brasileiro prestará, no que concerne ao meio ambiente, a necessária cooperação a outro país, sem qualquer ônus (...)”. Para detalhes, v. Milaré (2009, p. 1237-1238).

\section{REFERÊNCIAS BIBLIOGRÁFICAS}

ANDRESEN, Steinar. Global environmental governance: UN fragmentation and co-ordination. In: Stokke, Olav Schram; Thommessen, Øystein B. (Eds.) Yearbook of International Co-operation on Environment and Development 2001 /2002. London: Earthscan Publications, 2001.

AYALA, Patryck de Araújo. Direito ambiental e riscos tecnológicos: o princípio constitucional da imparcialidade no Direito ambiental brasileiro. Rio de Janeiro: Lumen Juris, 2011. 
. Direito e incerteza: a proteção jurídica das futuras gerações no Estado de Direito Ambiental.

Dissertação de Mestrado em Direito, Florianópolis, UFSC, 2002.

. Direito fundamental ao ambiente, mínimo existencial ecológico e proibição de retrocesso na ordem constitucional brasileira. São Paulo: Revista dos Tribunais, v. 901, p. 29-64, nov. 2010.

- Riscos biotecnológicos e o princípio constitucional da imparcialidade no direito ambiental brasileiro.

Rio de Janeiro: Lumen Juris, 2011.

- Constituição ambiental e sensibilidade ecológica: notas para a reflexão sobre um direito

ambiental de segunda geração na jurisprudência brasileira. Revista de Direito Ambiental, v. 60, p. 11-41, out./dez 2010.

. Tempo ambiental, necessidades ecológicas e o princípio constitucional da proporcionalidade no direito brasileiro. In: Benjamin, Antônio Herman V. (Org.) Anais do VI Congresso Internacional de Direito Ambiental, 3 a 6 de junho de 2002 (10 anos da ECO-92: o direito e o desenvolvimento sustentável). São Paulo: Imesp, 2002.

BODANSKY, Daniel. Costumary (and not so costumary) international environmental law. Indiana: Global Legal Studies Journal, v. 3, p. 105-119, 1995.

BRUNNÉE, Jutta. The Stockholm declaration and the structure and processes of international environmental law. In: Chircop, Aldo; McDorman, Ted; Rolston, Susan. (Eds.). The Future of Ocean Regime Building: Essays in Tribute to Douglas M. Johnstons. Doordrecht: Martinus Nijhoff, 2008. BRO-RASMUSSEN, Finn. Precautionary principle and/or risk assessement: a penitence in contemporany political culture. In: Ecomed, 1999.

BURHENNE-GUILMIN, Françoise. (Coord.) Environmental Law in Developing Countries: Selected Issues. Cambridge: IUCN, 2004. vol. II.

CANÇADO TRINDADE, Antônio Augusto. A proteção internacional dos direitos humanos: fundamentos jurídicos e instrumentos básicos. São Paulo: Saraiva, 1991.

CANOTILHO, José Joaquim Gomes. Direito constitucional ambiental português: tentativa de compreensão de 30 anos das gerações ambientais no direito constitucional português. In: Canotilho, José Joaquim Gomes; Leite, José Rubens Morato. (Orgs.) Direito constitucional ambiental brasileiro. 3. ed. São Paulo: Saraiva, 2009.

. Estado Constitucional e democracia sustentada. Coimbra: Revista do Centro de Estudos de Direito do Ordenamento, do Urbanismo e do Ambiente, IV, n. 8. p. 9-16, dez. 2001.

COMISSÃO DAS COMUNIDADES EUROPEIAS. Proposta de Diretiva do Parlamento Europeu e do Conselho relativa à proteção do ambiente através do Direito Penal, apresentada pela Comissão. COM (2001) 139 final. CONGRESSO INTERNACIONAL: O novo direito ambiental por Michel Prieur. Carta de São Paulo 2: sobre a Convenção de Aarhus. São Paulo: IEDC, Revista Internacional de Direito e Cidadania, n. 8. p. 209-210, out. 2010 .

DÍAZ REVORIO, Francisco Javier. La Constitución como Orden Abierto. Madrid: McGraw-Hill, 1997. DUPUY, René-Jean. La Clôture du Système International: La Cité Terrestre. Paris: PUF, 1989.

ENGEL, Christoph. The Constitucional Court - Applying the Proportionality Principle - as a Subsidiary Authority for the Assessment of Political Outcomes. Bonn: Max-Plank-Projektgruppe Recht der Gemeinschaftsgüter, 2001.

GOMES, Luiz Flávio; Mazzuoli, Valerio de Oliveira. Direito supraconstitucional: do absolutismo ao Estado Constitucional e Humanista de Direito. São Paulo: Ed. RT, 2010.

HÄBERLE, Peter. Teoria de la Constitución como Ciência de la Cultura. Tradução de Emilio Mikunda. Madrid: Tecnos, 2000.

JAYME, Erik. Identité culturelle et intégration: le droit international privé postmoderne. Recueil des Cours, v. 251, p. 9-267, 1995.

KISS, Alexandre; Shelton, Dinah. International Environmental Law. Leiden: Martinus Nijhoff, 2007.

LADEUR, Karl Heinz. The changing role of the private in public governance: the erosion of hierarchy and the rise of a new administrative law of cooperation - comparative approach. Florence: European University Institute, 2002.

LADEUR, Karl Heinz; Prelle, Rebecca. Environmental assessement and judicial approaches to procedural errors: a european and comparative law analysis. Journal of Environmental Law, v. 13, n. 2, p. 185-198, 2001.

MAZZUOLI, Valério de Oliveira. O controle jurisdicional da convencionalidade das leis. São Paulo: Ed. RT, 2009.

. Curso de direito internacional público. 5. ed. rev., atual. e ampl. São Paulo: Ed. RT, 2011. 
. A proteção internacional dos direitos humanos e o direito internacional do meio ambiente. Revista de Direito Ambiental, v. 34, p. 97-123, abr./jun. 2004.

. Il recepimento dei trattati internazionali in materia di ambiente nell'ordinamento giuridico brasiliano. In: Del Vecchio, Angela; Dal Ri Júnior, Arno. (Orgs.) Il Diritto Internazionale dell'Ambiente dopo il Vertice di Johannesburg. Napoli: Scientifica, 2005.

Tratados internacionais de direitos humanos e direito interno. São Paulo: Saraiva, 2010.

MILARÉ, Édis. Direito do ambiente. 6. ed. rev., atual. e ampl. São Paulo: Ed. RT, 2009.

MIRRA, Álvaro Luiz Valery. Princípios fundamentais do direito ambiental. Revista de Direito Ambiental, v. 2, p. 50-66, abr./jun. 1996.

PALLEMAERTS, Marc. Proceduralizing environmental rights: the Aarhus Convention on access to information, public participation in decision-making and access to Justice in environmental matters in a human rights context. Human rights and the environment: proceedings of a Geneva Environment Network roundtable. Geneva: United Nations Environment Programme for the Geneva Environment Network, 2004.

PETTS, Judith. Science, Society and Risk: Bridgning the Gap? Birmingham: University of Birmingham, 2002. ROSSIT, Liliana Allodi. Educação e cooperação internacional na proteção do meio ambiente. São Paulo: IOB Thomson, 2006.

SANDS, Philippe. Human rights and the environment: proceedings of a Geneva Environment Network roundtable. Geneva: United Nations Environment Programme for the Geneva Environment Network, 2004.

. Principles of International Environmental Law. 2. ed. Cambridge: Cambridge University Press, 2003.

SARLET, Ingo Wolfgang. Dignidade da pessoa humana e direitos fundamentais na Constituição Federal de 1988. 3. ed. rev., atual. e ampl. Porto Alegre: Livraria do Advogado, 2004.

SILVA, Solange Teles da. O direito ambiental internacional. Belo Horizonte: Del Rey, 2010.

SOARES, Guido Fernando Silva. A cooperação técnica internacional. In: Marcovitch, Jacques. (Org.) Cooperação internacional: estratégia e gestão. São Paulo: Edusp, 1994.

Atlas, 2003.

Direito internacional do meio ambiente: emergência, obrigações e responsabilidades. 2. ed. São Paulo:

WEISS, Edith Brown. The emerging international system and sustainable development. International Review for Environmental Strategies, v. 1, n. 1, p. 9-15, 2000.

\section{Valerio de Oliveira Mazzuoli}

Rua Buenos Aires, n. 280, ap. 1.003 Jardim das Américas - 78060-634

Cuiabá - MT - Brasil mazzuoliaufmt.br
Pós-DOUTOR EM CIÊnCIAS Jurídico-Políticas PELA UNIVERSIDADE DE LISBOA

DOUTOR SUMMA CUM LAUDE EM DIREITO INTERNACIONAL PELA UFRGS. MESTRE EM DIREITO INTERNACIONAL PELA UNESP

PROFESSOR NOS CURSOS DE GRADUAÇÃO E DE MESTRADO EM DIREITO dA UFMT

Coordenador do Programa de Mestrado EM DiREITO Agroambiental da UFMT

Membro efetivo da AsSociação BrasileEIRA de Constitucionalistas Democratas (ABCD) 
Patryck de Araújo Ayala

Rua Tenente Lira, n. 344 Bairro Dom Aquino - 78015-280 Cuiabá - MT - Brasil pkayaladaterra.com.br
Doutor e Mestre em Direito PELA UFSC, tendo REALIzado ESTÁGIO DE DOUTORAMENTO JUNTO À FACULDADE DE DIREITO DA UnIVERSIDADE DE LISBOA, NO ANO DE 2006 (PDEE/CAPES)

PROFESSOR NOS CURSOS DE GRADUACTÃO E DE MESTRADO EM DIREITO DA UFMT PESQUisador do grupo de PESQUisas "DiREITO AMBIENTAL e Ecologia Política na Sociedade de Risco" MeMBro da COMISSION ON ENVIRONMENTAL LAW (STEERING COMITEE) DA IUCN 